\title{
CALON TUNGGAL PILKADA KURANGI KUALITAS DEMOKRASI
}

Kajian Putusan Mahkamah Konstitusi Nomor 100/PUU-XIII/2015

\section{SINGLE CANDIDACY OF LOCAL HEAD ELECTIONS THAT HARMS THE QUALITY OF DEMOCRACY}

An Analysis of Constitutional Court Decision Number 100/PUU-XIII/2015

\author{
Muhammad Anwar Tanjung \& Retno Saraswati \\ KPU RI dan Program Doktor Ilmu Hukum Universitas Diponegoro \\ Jl. Imam Bardjo SH No. 1, Pleburan, Semarang 50241 \\ Email: 99tanjunganwar@gmail.com dan Saraswatiretno@yahoo.co.id
}

Naskah diterima: 1 Mei 2018; revisi: 19 November 2019; disetujui 19 Desember 2019

http://dx.doi.org/10.29123/jy.v12i3.319

\section{ABSTRAK}

Secara filosofis pemilihan kepala daerah merupakan pelaksanaan kedaulatan rakyat untuk dipilih dan memilih dalam suatu proses pemilihan yang berlangsung secara demokratis. Faktanya terjadi peningkatan jumlah daerah yang melaksanakan pemilihan kepala daerah dengan calon tunggal. Penelitian ini membahas calon tunggal dalam pemilihan kepala daerah berdasarkan pada Putusan Mahkamah Konstitusi Nomor 100/PUU-XIII/2015. Menurut peneliti putusan Mahkamah Konstitusi perlu disikapi oleh pemangku kepentingan yang terlibat untuk tetap menjaga proses pemilihan ini berlangsung secara demokratis. Penelitian ini termasuk penelitian non-doktrinal. Fakta terkini pemilihan kepala daerah dengan calon tunggal perlu dikawal sehingga pemilihan tetap berlangsung secara demokratis. Penelitian ini menyimpulkan calon tunggal dalam pemilihan kepala daerah memerlukan konstruksi hukum yang tepat (tidak dibiarkan terlepas) untuk menjamin demokrasi berjalan secara demokratis pasca Putusan Mahkamah Konstitusi Nomor 100/PUU-XIII/2015. Kerangka hukum harus menjamin pembatasan maksimal dukungan kursi calon kepala daerah yang diusung partai politik atau gabungan partai politik, sehingga dapat menghilangkan monopoli
\end{abstract}

individu atau kelompok pemodal terhadap persyaratan dukungan calon kepala daerah.

Kata kunci: pemilihan kepala daerah; calon tunggal; demokrasi.

\section{ABSTRACT}

Philosophically, regional head elections are the implementation of people's sovereignty to be elected and vote in a democratic election process. There has been an increase in the number of regional elections with a single candidate. This research discusses the only candidate in the election of regional heads based on the Constitutional Court Decision Number 100/ PUU-XIII/2015. According to researchers, the decision of the constitutional court needs to be addressed by the stakeholders that involved keeping the election process going on democratically. This study is non-doctrinal research. The latest facts about the election of a regional head with a single candidate need to be guarded so that the polls will continue democratically. This research concludes that a single candidate in the local head election requires an appropriate legal construction (not left aside) to ensure democracy runs democratically 
after the Constitutional Court Decision Number 100/ PUU-XIII/2015. The legal framework must guarantee the maximum support limitation for regional head candidate seats that carried by political parties or the association to eliminate the monopoly of individuals or groups of financiers regarding the support requirements of local head candidates.

Keywords: regional head election; single candidate; democracy.

\section{PENDAHULUAN}

\section{A. Latar Belakang}

Mahkamah Konstitusi mengeluarkan Putusan Mahkamah Konstitusi Nomor 100/PUUXIII/2015 tentang alas hukum calon tunggal dalam pemilihan kepala daerah (pilkada). Putusan tersebut lahir pada pelaksanaan pemilihan kepala daerah serentak tanggal 9 Desember 2015. Objeknya yakni pengujian konstitusionalitas Undang-Undang Nomor 8 Tahun 2015 tentang Perubahan Atas Undang-Undang Nomor 1 Tahun 2015 tentang Penetapan Peraturan Pemerintah Pengganti Undang-Undang Nomor 1 Tahun 2014 tentang Pemilihan Gubernur, Bupati, dan Walikota Menjadi Undang-Undang (Lembaran Negara Republik Indonesia Tahun 2015 Nomor 57, Tambahan Lembaran Negara Republik Indonesia Nomor 5678).

Pasal 1 angka 1 Undang-Undang Nomor 8 Tahun 2015 menyatakan pemilihan gubernur dan wakil gubernur, bupati dan wakil bupati, serta walikota dan wakil walikota yang selanjutnya disebut pemilihan adalah pelaksanaan kedaulatan rakyat di wilayah provinsi dan kabupaten/kota untuk memilih gubernur dan wakil gubernur, bupati dan wakil bupati, serta walikota dan wakil walikota secara langsung dan demokratis. Menunjuk Pasal 1 ayat(2) UUD NRI 1945 menyatakan kedaulatan berada di tangan rakyat dan dilaksanakan menurut Undang-Undang Dasar. Sebagai pelaksanaan kedaulatan rakyat maka pemilihan gubernur dan wakil gubernur, bupati dan wakil bupati, serta walikota dan wakil walikota harus menjamin terwujudnya kekuasaan tertinggi yang berada di tangan rakyat itu. Pasal 18 ayat (4) UUD NRI 1945 juga mengamanatkan bahwa kepala daerah harus dipilih secara demokratis.

Putusan Mahkamah Konstitusi Nomor 100/PUU-XIII/2015 menggunakan penafsiran sistematis terhadap norma a quo sehingga tampak pembentuk undang-undang bermaksud menyatakan dalam kontestasi pemilihan kepala daerah setidak-tidaknya harus ada dua pasangan calon. Namun di lain pihak tidak memberikan jalan keluar seandainya syarat dua pasangan calon tersebut tidak terpenuhi. Terdapat "kekosongan hukum" bila syarat paling kurang dua pasangan calon tersebut tidak terpenuhi. Kekosongan hukum akan berakibat tidak dapat diselenggarakannya pemilihan kepala daerah. Pemilihan kepala daerah merupakan pelaksanaan kedaulatan rakyat sehingga kekosongan hukum mengancam hak rakyat selaku pemegang kedaulatan berupa hak untuk dipilih maupun hak untuk memilih. Rakyat menjadi tidak dapat melaksanakan hak dimaksud karena dua pasangan calon tidak terpenuhi.

Munculnya Peraturan Komisi Pemilihan Umum (KPU) tidak menyelesaikan persoalan karena hak rakyat untuk dipilih dan memilih tetap saja tidak dapat dilaksanakan. Pasal 54 ayat (5) Peraturan KPU Nomor 12 Tahun 2015 tersebut menyatakan, sampai dengan berakhirnya pembukaan kembali masa pendaftaran hanya 
terdapat satu pasangan calon atau tidak ada pasangan calon yang mendaftar sebagaimana dimaksud, Komisi Pemilihan Umum Provinsi/ KIP Aceh atau Komisi Pemilihan Umum/KIP kabupaten/kotamenetapkankeputusan penundaan seluruh tahapan dan pemilihan diselenggarakan pada pemilihan serentak berikutnya.

Pemberlakuan peraturan a quo tidak menyelesaikan persoalan karena: pertama, penundaan ke pemilihan serentak berikutnya sesungguhnya telah menghilangkan hak rakyat untuk dipilih dan memilih pada pemilihan serentak saat itu. Kedua, penundaan dapat dibenarkan tetapi tidak ada jaminan bahwa pada pemilihan serentak berikutnya hak rakyat untuk dipilih dan memilih akan dapat dipenuhi. Hal itu dikarenakan potensi tidak dapat dipenuhinya hak rakyat untuk dipilih dan memilih itu tetap ada, yaitu ketentuan yang mempersyaratkan paling sedikit adanya dua pasangan calon dalam kontestasi pemilihan kepala daerah. Dalam perkembangan pemilihan kepala daerah memperlihatkan praktik politik kartel; politik kekerabatan atau dinasti (Harjanto, 2011:138-59). Akibat jangka panjang melahirkan kehidupan partai politik yang bersifat oligarkis, elitis, dan personalistis (Supriyanto \& Wulandari, 2012:4-6).

Hak konstitusional warga negara merupakan wujud pelaksanaan kedaulatan rakyat untuk dipilih dan memilih dalam pemilihan kepala daerah harus tetap dijamin, tanpa tersandera oleh syarat paling sedikit adanya dua pasangan calon kepala daerah dan wakil kepala daerah. Penundaan tersebut bertentangan dengan semangat UUD NRI 1945 jika pemilihan kepala daerah tidak dilaksanakan dan ditunda sampai pemilihan berikutnya. Hak konstitusional menjadi dirugikan yakni hak untuk dipilih dan memilih hanya karena tak terpenuhinya syarat paling sedikit adanya dua pasangan calon kepala daerah dan calon wakil kepala daerah, meskipun sudah diusahakan dengan sungguh-sungguh. Untuk menjamin hak konstitusional warga negara pemilihan kepala daerah harus tetap dilaksanakan meskipun hanya terdapat satu pasangan calon kepala daerah dan calon wakil kepala daerah.

Berlakunya Undang-Undang Nomor 8 Tahun 2015 a quo telah menimbulkan kerugian konstitusional. Adapun kerugian tersebut yakni:

1. Partai politik dan gabungan partai politik tidak mengusulkan pasangan calon dengan tujuan pemilihan kepala daerah di daerah tertentu tidak dapat terlaksana dan ditunda ke pemilihan serentak selanjutnya;

2. Partai politik dan gabungan partai politik tidak mengusulkan pasangan calon karena hanya akan menghabiskan sumber daya, biaya, energi, waktu, dan sebagainya secara sia-sia karena kuatnya elektabilitas calon;

3. Sulit dan rumitnya pemenuhan persyaratan calon perseorangan pada pemilihan kepala daerah mengakibatkan tidak adanya calon perseorangan yang muncul;

4. Upaya sungguh-sungguh untuk menghadirkan calon kepala daerah melalui perpanjangan masa pendaftaran sulit dipenuhi sehingga berpotensi tertunda sampai pemilihan serentak selanjutnya (Februari 2017).

5. Kekhawatiran munculnya calon boneka oleh sekelompok pasangan calon dalam rangka menghindari ketentuan setidaknya terdapat dua pasangan calon pada pemilihan kepala daerah mengancam demokrasi Indonesia. 
Berkenaan hal tersebut Mahkamah Konstitusi telah menjatuhkan Putusan Mahkamah Konstitusi Nomor 100/PUU-XIII/2015, adapun ringkasan amar putusannya yakni menyatakan mengabulkan permohonan pemohon untuk sebagian, yaitu:

1. Menyatakan Pasal 49 ayat (9) UndangUndang Nomor 8 Tahun 2015 bertentangan dengan Undang-Undang Dasar Negara Republik Indonesia Tahun 1945 sepanjang tidak dimaknai mencakup pengertian "termasuk menetapkan 1 (satu) pasangan calon gubernur dan calon wakil gubernur peserta Pemilihan dalam hal setelah jangka waktu 3 (tiga) hari dimaksud terlampaui namun tetap hanya ada 1 (satu) pasangan calon gubernur dan calon wakil gubernur";

2. Menyatakan Pasal 49 ayat (9) UndangUndang Nomor 8 Tahun 2015 tidak mempunyai kekuatan hukum mengikat sepanjang tidak dimaknai mencakup pengertian "termasuk menetapkan 1 (satu) pasangan calon gubernur dan calon wakil gubernur peserta pemilihan dalam hal setelah jangka waktu 3 (tiga) hari dimaksud terlampaui namun tetap hanya ada 1 (satu) pasangan calon gubernur dan calon wakil gubernur";

3. Menyatakan Pasal 50 ayat (9) UndangUndang Nomor 8 Tahun 2015 bertentangan dengan Undang-Undang Dasar Negara Republik Indonesia Tahun 1945 sepanjang tidak dimaknai mencakup pengertian "termasuk menetapkan 1 (satu) pasangan calon bupati dan calon wakil bupati serta 1 (satu) pasangan calon walikota dan calon wakil walikota peserta pemilihan dalam hal setelah jangka waktu 3 (tiga) hari dimaksud terlampaui namun tetap hanya ada 1 (satu) pasangan calon bupati dan calon wakil bupati serta 1 (satu) pasangan calon walikota dan calon wakil walikota";

4. Menyatakan Pasal 50 ayat (9) UndangUndang Nomor 8 Tahun 2015 tidak mempunyai kekuatan hukum mengikat sepanjang tidak dimaknai mencakup pengertian "termasuk menetapkan 1 (satu) pasangan calon bupati dan calon wakil bupati serta 1 (satu) pasangan calon walikota dan calon wakil walikota peserta pemilihan dalam hal setelah jangka waktu 3 (tiga) hari dimaksud terlampaui namun tetap hanya ada 1 (satu) pasangan calon bupati dan calon wakil bupati serta 1 (satu) pasangan calon walikota dan calon wakil walikota.

5. Menyatakan Pasal 51 ayat (2) UndangUndang Nomor 8 Tahun 2015 bertentangan dengan Undang-Undang Dasar Negara Republik Indonesia Tahun 1945 sepanjang tidak dimaknai mencakup "menetapkan 1 (satu) pasangan calon gubernur dan calon wakil gubernur dalam hal hanya terdapat 1 (satu) pasangan calon gubernur dan calon wakil gubernur";

6. Menyatakan Pasal 51 ayat (2) UndangUndang Nomor 8 Tahun 2015 tidak mempunyai kekuatan hukum mengikat sepanjang tidak dimaknai mencakup "menetapkan 1 (satu) pasangan calon gubernur dan calon wakil gubernur dalam hal hanya terdapat 1 (satu) pasangan calon gubernur dan calon wakil gubernur";

7. Menyatakan Pasal 52 ayat (2) UndangUndang Nomor 8 Tahun 2015 bertentangan 
dengan Undang-Undang Dasar Negara Republik Indonesia Tahun 1945 sepanjang tidak dimaknai mencakup "menetapkan 1 (satu) pasangan calon bupati dan calon wakil bupati serta 1 (satu) pasangan calon walikota dan calon wakil walikota dalam hal hanya terdapat 1 (satu) pasangan calon bupati dan calon wakil bupati serta 1 (satu) pasangan calon walikota dan calon wakil walikota";

8. Menyatakan Pasal 52 ayat (2) UndangUndang Nomor 8 Tahun 2015 tidak mempunyai kekuatan hukum mengikat sepanjang tidak dimaknai mencakup “menetapkan 1 (satu) pasangan calon bupati dan calon wakil bupati serta 1 (satu) pasangan calon walikota dan calon wakil walikota dalam hal hanya terdapat 1 (satu) pasangan calon bupati dan calon wakil bupati serta 1 (satu) pasangan calon walikota dan calon wakil walikota."

Dalam putusan tersebut terdapat dissenting opinion dari satu orang hakim konstitusi yang menyatakan bahwa:

1. Rumusan Undang-Undang Nomor 8 Tahun 2015 sudah tepat, yaitu pasangan calon dalam pilkada paling sedikit dua pasangan calon dengan demikian pasal tersebut konstitusional.

2. Persyaratan-persyaratan seorang calon pemilukada adalah subjek hukum. Pemilihan yang dilakukan untuk memilih kepala daerah adalah subjek hukum, di mana subjek hukum tersebut adalah orang yang memenuhi persyaratan yang ditentukan oleh peraturan perundangundangan. Oleh karena itu calon kepala daerah sebagai subjek hukum disandingkan dengan non-subjek hukum (pernyataan setuju atau tidak setuju/referendum). Pilkada bukan merupakan referendum akan tetapi pemilihan dari beberapa pilihan atau lebih dari satu untuk dipilih. Semua penyelenggara pilkada baik KPU, Bawaslu, dan DKPP pada dasarnya harus memberlakukan pasangan calon kepala daerah dan wakil kepala daerah secara adil dan setara. Bagaimana mungkin kewajiban penyelenggara pilkada tersebut memberlakukan secara adil pasangan calon kepala daerah dengan setuju atau tidak setuju yang bukan subjek hukum. Menurut penalaran akal sehat dan wajar pastilah penyelenggara pilkada tidak bisa memperlakukan secara setara dan adil terhadap pasangan calon yang abstrak atau pernyataan setuju atau tidak setuju.

3. Apabila calon tunggal dibenarkan dalam pilkada, maka bisa jadi suatu saat akan terjadi penyelundupan hukum. Hal tersebut dikuatirkan akan melahirkan liberalisasi yang dilakukan oleh para pemilik modal untuk 'membeli' partai politik untuk hanya mencalonkan satu pasangan saja sehingga kesempatan untuk menang bagi calon independen tipis. Agar adanya pasangan calon lain seyogianya persyaratan calon independen lebih dipermudah.

4. Apabila dibenarkan adanya calon tunggal, hakim konstitusi (dissenting opinion) berpendapat bahwa Mahkamah Konstitusi terlalu jauh masuk pada kewenangan pembentuk undang-undang.

5. Berkaitan dengan tidak adanya jalan keluar dalam hal tidak terpenuhinya syarat paling sedikit dua pasangan calon tersebut, pada 
dasarnya undang-undang a quo telah mengakomodir apabila pasangan calon dalam pemilihan kepala daerah kurang dari dua pasangan calon yaitu dengan adanya penundaan. Seyogianya bagi daerah yang calonnya kurang dari dua pasangan calon, maka pemilihan tersebut ditunda sesuai tenggang waktu yang ditentukan oleh pembuat undang-undang. Tanggung jawab untuk memenuhi pasangan calon tersebut berada pada partai-partai politik yang berhak mencalonkan calon kepala daerah.

6. Kedudukan calon tunggal dalam pilkada apabila dilihat dilihat dari asas pemilu langsung, umum, bebas, rahasia, jujur, dan adil (Luber dan Jurdil). Keberadaan calon tunggal pada dasarnya meniadakan kontestasi. Pemilu tanpa kontestasi hakikatnya bukan pemilu yang senafas dengan asas Luber dan Jurdil. Hak-hak untuk memilih dan hak untuk dipilih akan terkurangi dengan adanya calon tunggal karena pemilih dihadapkan pada pilihan $\operatorname{artifisial~(semu).~}$

Posisi Putusan Mahkamah Konstitusi Nomor 100/PUU-XIII/2015 semenjak diputuskan telah menjadi alas hukum yang bersifat yuridis normatif yang bersifat preskriptif serta konstitusional. Namun demikian Mahkamah Konstitusi selalu membuka ruang dengan memperhatikan dinamika perkembangan masyarakat sebagaimana putusan Mahkamah Konstitusi yang pernah merujuk dan menyempurnakan putusan yang sebelumnya berkenaan dengan calon kepala daerah yang berstatus tersangka. Harapan itu kiranya sebuah harapan untuk melihat perkembangan yang terjadi.

Fakta empiris calon tunggal dalam pemilihan kepala daerah terus meningkat.
Pemilihan kepala daerah tahun 2015 diikuti tiga kandidat. Pemilihan kepala daerah tahun 2017 terdapat sembilan daerah yang diisi dengan calon tunggal. Pemilihan kepala daerah tahun 2018 terdapat 13 daerah dengan calon tunggal. Kesemua daerah dengan calon tunggal dilantik jadi kepala daerah (menang dalam kontestasi) (www.kpu.go.id).

Fakta ini menarik untuk dikaji sebagai bagian dari proses pembangunan demokrasi. Fakta bahwa demokrasi Indonesia telah berada pada titik puncak sehingga calon tunggal menjadi pilihan hati nurani rakyat. Keyakinan masyarakat bahwa calon tunggal adalah calon yang paling terbaik sehingga rakyat setuju hal tersebut. Atau sebaliknya Indonesia sedang menuju kemerosotan demokrasi melalui calon tunggal. Ketiadaan pilihan lain yang tersaji membuat rakyat menjadi take it for granted dalam pemilihan calon kepala daerah yang diikuti oleh calon tunggal.

\section{B. Rumusan Masalah}

Fakta bahwa calon tunggal ini akan terus meningkat di pemilihan kepala daerah sangat mungkin terjadi. Kemenangan hampir pasti diperoleh sang kandidat. Putusan Mahkamah Konstitusi Nomor 100/PUU-XIII/2015 tentang alas hukum calon tunggal dalam pemilihan kepala daerah bertujuan untuk mengisi kekosongan hukum terhadap permasalahan pemilihan kepala daerah. Bukan sebaliknya dimanfaatkan sebagai jalan untuk memperoleh kekuasaan oleh sekelompok orang. Berdasarkan hal tersebut permasalahan yang dikaji dalam penelitian ini adalah bagaimana menjaga kualitas demokrasi di tengah meningkatnya calon tunggal dalam pemilihan kepala daerah pasca Putusan Mahkamah Konstitusi Nomor 100/PUU-XIII/2015? 


\section{Tujuan dan Kegunaan}

Tujuan dari penelitian ini adalah untuk menganalisis perkembangan terkini calon tunggal pemilihan kepala daerah pasca Putusan Mahkamah Konstitusi Nomor 100/PUUXIII/2015. Adapun kegunaan yang diperoleh secara praktis adalah untuk memberikan pengetahuan dan pemahaman bagi penegak hukum khususnya hakim dan pembentuk undangundang dalam rangka melakukan pembaruan hukum pemilu yang berkenaan dengan eksistensi calon tunggal dalam pemilihan kepala daerah.

\section{Tinjauan Pustaka \\ 1. Pengertian Demokrasi}

Demokrasi adalah pemerintahan oleh rakyat yang memosisikan bahwa dalam suatu organisasi negara rakyatlah yang berdaulat (Prodjodikoro, 1981:22-23). Pemerintahan yang demokratis biasanya menjadikan pemilihan umum (pemilu) sebagai sarana untuk memilih pemimpinnya hingga pada level desa sekalipun (Maschab, 2013:75).

Pemilu (general election) merupakan ciri penting yang harus dilaksanakan secara berkala dalam waktu-waktu tertentu (Asshiddiqie, 2011:414). Dalam hal ini, demokrasi diartikan sebagai"suatusistempemerintahandimanamereka yang mempunyai kekuasaan untuk membuat keputusan memperoleh dan mempertahankan kekuasaan secara langsung ataupun tidak langsung sebagai hasil memenangkan pemilu yang bebas di mana sebagian besar rakyat dimungkinkan untuk berpartisipasi (Burns, Peltason, \& Cronin, 1989:3).

Tingginya partisipasi menunjukkan sistem demokrasi yang berjalan sudah dianggap baik dan dipercaya oleh warga negara (Nurhasim, 2014:16). Dalam hal ini negara harus menjamin perlakuan yang sama untuk terlibat dalam pemerintahan (Gaffar, 2013:18-19). Partisipasi seseorang dalam bidang sosial dan politik merupakan bentuk tingkah laku sosial yang dipengaruhi oleh nilai-nilai yang dianutnya. Sistem pemilihan kepala daerah secara langsung memberikan kebebasan sepenuhnya bagi masyarakat pemilih untuk menentukan siapa kandidat kepala daerah yang akan terpilih (Pangi, 2012:65).

Demokrasi menurut Lincoln adalah suatu bentuk pemerintahan di mana kekuasaan politik tertinggi dan kedaulatan berada di tangan rakyat. Karena itu pemerintahan yang demokratis adalah pemerintahan yang mendapat persetujuan rakyat atau pemerintahan yang sudah memiliki mandat untuk memerintah dari rakyat (Nurtjahjo, 2006:74). Demokrasi adalah tingkat terakhir rakyat memberikan ketentuan dalam masalahmasalah pokok mengenai kehidupannya, termasuk dalam menilai kebijakan negara karena kebijakan tersebut menentukan kehidupan rakyat (Noer, 1983:207). Selain itu demokrasi juga berarti bentuk pemerintahan sesuatu persekutuan yang berpemerintahan sendiri, dalam hal mana sebagian besar warganya turut mengambil bagian dalam persekutuan kaum ini, walaupun masih sederhana ciri tersebut sudah ditemui.

Hague \& Harrop (2001:16) mengartikan demokrasi dari dua kata, yaitu: rule (kratos) by the people (demos). Thus democracy in its literal and riches sense-refers not to be the lections of the rules by the ruled but to the denialof any separation between the two. Terjemahan demokrasi berasal dari kata Yunani "demokratia" yang artinya kekuasaan atau aturan. Selanjutnya demos mengandung arti rakyat, meskipun pada 
awalnya di zaman Yunani, kata "rakyat" tersebut digubahkan dalam pengertian "orang sedikit" atau "orang banyak."

Demokrasi dipahami sebagian sebagai peringkat atau derajat dan sebagian lagi ada yang memahami sebagai mekanisme tertentu melalui mana kehendak umum diekspresikan (Maciver, 1955:351). Schumpeter (1974:269) memberi makna demokrasi sebagai sebuah sistem untuk membuat keputusan-keputusan politik di mana individu-individu mendapatkan kekuasaan untuk memutuskan melalui pertarungan kompetitif memperebutkan suara rakyat.

Huntington (1989:15) menyebutkan bahwa prosedur utama demokrasi adalah pemilihan para pemimpin secara kompetitif oleh rakyat yang mereka bakal pimpin. Selain itu pemilu sangat sejalan dengan demokrasi secara substansi atau “demokrasi substansial" yakni demokrasi dalam pengertian pemerintahan yang diselenggarakan dari rakyat, oleh rakyat, dan untuk rakyat. Artinya rakyatlah yang memegang kekuasaan tertinggi (kedaulatan).

Dalam konsep ilmu hukum (tata negara) demokrasi mengandung arti bahwa kekuasaan tertinggi dalam urusan-urusan politik merupakan hak rakyat. Dalam UUD NRI 1945 misalnya konsep demokrasi ini ditemukan pada Pasal 1 ayat (2) yang menegaskan bahwa kedaulatan ada di tangan rakyat (Thaib, 1999:55). Dalam rangka melaksanakan nilai-nilai demokrasi menurut Huda (2005:245) perlu diselenggarakan beberapa lembaga yaitu:

a. Pemerintahan yang bertanggung jawab.

b. Suatu dewan perwakilan rakyat yang mewakili golongan-golongan dan kepentingan-kepentingan dalam masyarakat dan yang dipilih melalui pemilihan umum yang bebas dan rahasia dan atas dasar sekurangkurangnya dua calon untuk setiap kursi.

c. Suatu organisasi politik yang mencakup satu atau lebih partai politik.

d. Pers dan media massa yang bebas untuk menyatakan pendapat.

e. Sistem peradilan yang bebas untuk menjamin hak-hak asasi dan mempertahankan keadilan.

Ketentuan Pasal 24C ayat (1) UUD NRI 1945 jo. Pasal 10 ayat (1) huruf a Undang-Undang Nomor 24 Tahun 2003 tentang Mahkamah Konstitusi sebagaimana telah diubah UndangUndang Nomor 8 Tahun 2011 tentang Perubahan Atas Undang-Undang Nomor 24 Tahun 2003 tentang Mahkamah Konstitusi menyebutkan bahwa salah satu kewenangan Mahkamah Konstitusi adalah melakukan pengujian undangundang terhadap UUD NRI 1945.

Universal Declaration on Democracy yang diadopsi oleh Inter-Parliamentary Union (IPU, 1997), pemilu merupakan elemen kunci untuk menjalankan demokrasi. Bagian kedua angka angka 12 deklarasi ini menyatakan:

"The key element in the exercise of democracy is the holding of free and fair elections at regular intervals enabling the people's will to be expressed. These elections must be held on the basis of universal, equal and secret suffrage so that all voters can choose their representatives in conditions of equality, opennes and transparency that stimulate political competition. To that end, civil and political rights are essential and more particularly among them, the rights to vote and to be elected, the rights to freedom of expressions and assembly, access to information and the right to organise political parties and carry out political activities. Party organisation, activities, finances, funding and ethics must be properly regulated in an impartial 
manner in order to ensure the integrity of the democratic processes."

"Elemen kunci dalam menjalankan demokrasi adalah diadakannya pemilihan umum yang bebas dan adil secara berkala yang memungkinkan kehendak rakyat untuk diekspresikan. Pemilihan ini harus diselenggarakan atas dasar universal, sama, dan rahasia sehingga semua pemilih dapat memilih wakil-wakil mereka dalam kondisi kesetaraan, keterbukaan, dan transparansi yang merangsang persaingan politik. Untuk itu, hak-hak sipil dan politik yang penting dan lebih khusus di antara mereka, hak untuk memilih dan dipilih, hak untuk kebebasan ekspresi, akses informasi dan hak untuk mengatur partai politik dan melaksanakan kegiatan politik. Partai organisasi, kegiatan, keuangan, pendanaan, dan etika harus benar diatur secara berimbang dalam rangka untuk memastikan integritas dari proses demokrasi."

\section{Pemilihan Kepala Daerah Demokratis}

Pemilu guna membentuk sistem kekuasaan negara yang berkedaulatan rakyat, memiliki fungsi-fungsi (Pamungkas, 2009:5), yaitu: pertama, fungsi untuk mengatur prosedur seseorang untuk dipilih menjadi anggota badan perwakilan rakyat atau menjadi kepala pemerintahan; kedua, pemilu sebagai mekanisme pergantian atau sirkulasi elit penguasa; ketiga, fungsi perwakilan politik, pemilu merupakan mekanisme demokratis bagi rakyat untuk menentukan wakil-wakil yang dipercaya yang duduk dalam pemerintahan maupun lembaga legislatif; keempat, sebagai sarana legitimasi politik sehingga keabsahan pemerintahan yang berkuasa dapat ditegakkan; dan kelima, sebagai sarana pendidikan politik bagi rakyat.

Kerangka hukum pemilihan kepala daerah harus dapat menjamin terselenggaranya pemilihan yang demokratis. Mackanzie (Pamungkas, 2009:5) menyebutkan empat kondisi agar pemilu yang demokratis dan terlembaga dapat berkesinambungan, yaitu:

a. Adanya pengadilan independen yang mengintegrasikan peraturan pemilu;

b. Adanya lembaga administrasi yang jujur, kompeten, dan non-partisan untuk menjalankan pemilu;

c. Adanya pembangunan sistem kepartaian yang cukup terorganisir untuk meletakkan pemimpin dan kebijakan di antara alternatif kebijakan yang dipilih;

d. Penerimaan komunitas politik terhadap aturan main tertentu dari struktur dan pembatasan dalam mencapai kekuasaan.

Karim (1991:6) mengutip Ranney, menyebutkan ciri-ciri pemilu yang demokratis ada delapan, yaitu:

a. Diselenggarakan secara reguler;

b. Pemilihan yang benar-benar berarti;

c. Kebebasan menentukan calon;

d. Kebebasan mengetahui dan mendiskusikan pilihan-pilihan;

e. Hak pilih orang dewasa yang universal;

f. Perlakuan yang sama dalam pemberian suara;

g. Pendaftaran pemilih yang bebas;

h. Perhitungan pemilihan dan pelaporan hasil yang tepat.

Organisasi parlemen sedunia (InterParliamentary Union) telah membuat dokumen Universal Declaration on Democracy yang di dalamnya juga menyebutkan prinsip-prinsip pemilu yang demokratis yang meliputi:
a. Prinsip free, fair, dan regular sehingga kehendak rakyat dapat diekspresikan.
b. Prinsip pelaksanaan pemilu berdasarkan hak pilih yang bersifat umum, sederajat, dan rahasia sehingga pemilih dapat memilih wakilnya dalam kondisi secara sama (equal), dalam situasi yang terbuka dan transparan yang mendorong kompetisi politik. 
Semua prinsip-prinsip pemilu di atas harus mewujud dalam electoral laws serta dilaksanakan dalam electoral process. Oleh karena itu prinsipprinsip tersebut harus tercermin di dalam sepuluh komponen dari pemilu demokratis sebagaimana dinyatakan oleh Office For Democratisc Institutions and Human Rights, yaitu: sistem pemilu (elections systems); pengaturan distrik (districting); administrasi pemilu (election administration); hak pilih dan pendaftaran pemilih (suffarage rights and voter registration); pendidikan kewarganegaraan dan informasi pemilih (civic education and voter information); kandidat, partai politik, dan pendanaan kampanye (candidates, political parties, and campaign spending); akses media dan perlindungan kebebasan berbicara dan berekspresi di dalam kampanye (media access and protection freedom of speech and expression in electoral campaigns); pemungutan suara (balloting); pemantauan pemilu (election observation); dan penyelesaian sengketa pemilu (resolution of election disputes) (Office for Democratic Institutions and Human Rights, 2002).

\section{Konsep Hukum Progresif}

Gagasan hukum progresif dimulai dari asumsi dasar filosofis bahwa hukum adalah untuk manusia bukan sebaliknya. Dengan demikian keberadaan hukum adalah untuk melayani dan melindungi manusia bukan sebaliknya. Hukum dianggap sebagai institusi yang bertujuan mengantarkan manusia kepada kehidupan yang adil dan sejahtera, dan membuat manusia bahagia. Hukum progresif menganut ideologi hukum yang pro-keadilan dan hukum yang prorakyat (Rahardjo, 2009:6).

Rahardjo menggambarkan bahwa hukum selalu dalam proses dengan mengatakan bahwa: hukum adalah institusi yang secara terus-menerus membangun dan mengubah dirinya menuju kepada tingkat kesempurnaan yang lebih baik. Kualitas kesempurnaan di sini bisa diverifikasi ke dalam faktor-faktor keadilan, kesejahteraan, kepedulian kepada masyarakat, dan lain-lain. Inilah hakikat "hukum selalu dalam proses menjadi" (law as process, law in the making). Hukum tidak ada untuk hukum itu sendiri tetapi untuk manusia (Rahardjo, 2005:6).

Hukum yang senantiasa berproses menjadi yang dapat diverifikasi dalam ukuran keadilan, kesejahteraan, dan keberpihakan pada rakyat, sudah barang tentu sangat dipengaruhi oleh manusia-manusia yang menjalankan hukum dalam proses menjadi tersebut. Memang hukum itu tidak bisa melepaskan diri dari dirinya yag normatif sebagai rules, tetapi hukum juga sebagai perilaku. Peraturan akan membangun suatu hukum positif, sedangkan perilaku atau manusia akan menggerakkan peraturan dan sistem yang sudah dibangun itu.

Hal ini penting karena sebagai peraturan hukum itu hanya kata-kata dan rumusan di atas kertas tapi nyaris tidak berdaya sama sekali. Sehingga sering disebut sebagai black letter law, law in paper, law in the books. Hukum hanya bisa menjadi kenyataan dan janji-janji dalam hukum terwujud, apabila ada campur tangan manusia (Rahardjo, 2005:3). Karakter hukum progresif adalah:

1. Penemuan hukum yang didasarkan atas apresiasi hakim sendiri dengan dibimbing oleh pandangannya dan pemikirannya secara mandiri, dengan berpijak pada pandangan bahwa hukum itu ada untuk mengabdi kepada manusia.

2. Penemuan hukum yang bersandarkan pada nilai-nilai hukum, kebenaran, 
dan keadilan serta juga etika dan moralitas.

3. Penemuan hukum yang mampu menciptakan nilai-nilai baru dalam kehidupan masyarakat, atau melakukan rekayasa dalam masyarakat sesuai dengan perkembangan zaman dan teknologi serta keadaan masyarakat (Rivai, 2010:48).

\section{METODE}

Penelitian ini merupakan penelitian non-doktrinal dengan menggunakan metode kualitatif (Moleong, 2012:31-32). Penelitian ini menggunakan data bahan hukum primer berupa peraturan perundang-undangan dan putusanputusan Mahkamah Konstitusi terkait, dan bahan hukum sekunder berupa buku-buku ilmiah dan hasil penelitian. Data diperoleh melalui studi dokumen, kemudian bahan yang terkumpul diinventarisasi dan disistematisasi, selanjutnya dikaji dan dianalisis untuk menjawab permasalahan.

\section{HASIL DAN PEMBAHASAN}

Menurut Sri Mulyani dalam kuliah umum dalam rangka Dies Natalis Fakultas Ekonomi dan Bisnis Universitas Diponegoro Semarang tahun 2018, ada empat hal yang harus disiapkan menuju Indonesia Emas 2045, yakni: kualitas sumber daya manusia; infrastruktur; kualitas kelembagaan agar profesional dan tidak korup; dan kebijakan pemerintah. Pemilihan gubernur dan wakil gubernur, bupati dan wakil bupati, serta walikota dan wakil walikota adalah pelaksanaan kedaulatan rakyat di wilayah provinsi dan kabupaten/kota untuk memilih gubernur dan wakil gubernur, bupati dan wakil bupati, serta walikota dan wakil walikota secara langsung dan demokratis.
Melalui penafsiran sistematis Mahkamah Konstitusi menyimpulkan terdapat kekosongan hukum manakala syarat paling kurang dua pasangan calon tersebut tidak terpenuhi. Kekosongan hukum berakibat pada tidak dapat diselenggarakannya pemilihan kepala daerah. Sedangkan pemilihan kepala daerah merupakan pelaksanaan kedaulatan rakyat, sehingga kekosongan hukum demikian mengancam hak rakyat selaku pemegang kedaulatan, baik hak untuk dipilih maupun hak untuk memilih sebab rakyat menjadi tidak dapat melaksanakan haknya. Itulah yang menjadi sumber hukum pemilihan kepala daerah dengan calon tunggal.

Kekhawatiran pemilihan kepala daerah dengan calon tunggal akan menurunkan kualitas demokrasi sudah terpikirkan. Apabila calon tunggal dibenarkan dalam pemilihan kepala daerah, maka bisa jadi suatu saat akan terjadi penyelundupan hukum. Hal tersebut dikuatirkan akan melahirkan liberalisasi yang dilakukan oleh para pemilik modal untuk 'membeli' partai politik untuk hanya mencalonkan 1 (satu) pasangan saja dengan melihat kejadian di beberapa daerah dengan calon tunggal. Secara langsung atau tidak langsung dissenting opinion memberikan jalan keluar agar persyaratan calon independen lebih dipermudah dalam hal antisipasi penyelendupan hukum yang mungkin terjadi.

Kualitas demokrasi di tengah meningkatnya calon tunggal dalam pemilihan kepala daerah harus tetap dijamin. Fakta bahwa masyarakat Indonesia berada pada peringkat ke-64 dengan nilai 69,7 yang didasarkan pada tingkat buta huruf dan kemampuan berhitung masih tergolong rendah (WEF, 2017) memerlukan tindakan terstruktur, sistematis, dan masif dalam melakukan pendidikan politik. Hal ini berkaitan dengan kesadaran politik dan kualitas demokrasi 
di daerah tersebut. Kelemahan ini tidak harus digunakan sebagai senjata oleh sekelompok orang untuk merebut kekuasaan.

Sadar bahwa subjek hukum pemilihan kepala daerah adalah orang (calon kepala daerah) disandingkan dengan non-subjek hukum (pernyataan setuju atau tidak setuju/referendum) merupakan ketidaksamaan. Subjek hukum dapat memperkenalkan dirinya, mengkampanyekan visi misinya untuk dapat menarik hati para pemilih. Namun di lain sisi non-subjek hukum (pernyataan setuju atau tidak setuju) bersifat pasif. Selain itu pengetahuan masyarakat akan model pemilihan dengan calon tunggal masih baru.

Kecenderungan masyarakat untuk memilih yang terdapat gambar calon lebih tinggi. Hal ini dikarenakan faktor kebiasaan dan pengetahuan masyarakat di beberapa daerah masih rendah. Gagap atau bingung memengaruhi suara pemilih di bilik suara sehingga memilih dipastikan berdasarkan kebiasaan, bukan berdasarkan kelayakan dan kepantasan seseorang calon untuk memimpin.

Semangat Putusan Mahkamah Konstitusi Nomor 100/PUU-XIII/2015 dalam pemilihan kepala daerah yang hanya diikuti oleh satu pasangan calon haruslah dipahami. Pemilihan kepala daerah dengan calon tunggal ditempatkan sebagai upaya terakhir semata-mata demi memenuhi hak konstitusional warga negara setelah sebelumnya diusahakan dengan sungguhsungguh untuk menemukan paling sedikit dua pasangan calon. Semangat ini akan hilang bilamana di proses awal seluruh persyaratan untuk mengusung calon kepala daerah "telah ditutup." Mekanisme jumlah kursi untuk mengusung calon tidak mungkin lagi. Mekanisme suara sah juga sulit dipenuhi. Hal ini tentunya tidak sejalan dengan keinginan konstitusi.

Partai politik dan gabungan partai politik tidak mengusulkan pasangan calon sehingga memunculkan satu pasangan calon. Partai politik dan gabungan partai politik sepakat mengusulkan satu pasangan calon. Hal ini dilakukan dengan maksud memonopoli proses pencalonan yang diusung oleh partai politik atau gabungan partai politik. Demokrasi adalah tentang persamaan politik dan memberi semua orang kesetaraan suara untuk turut menentukan bagaimana suatu negara harus diatur atau dijalankan (Hix \& Whiting, 2012:31). Bilamana hal tersebut terjadi maka demokrasi terancam. Konstitusi menjadi tidak berdaya terhadap fiksi yang terjadi. Untuk itu perlu konsep baru (rekonsep) terhadap suatu persoalan dan berani keluar dari status quo.

Hukum hendaknya mampu mengikuti perkembangan zaman, mampu menjawab perubahan zaman, dengan segala dasar di dalamnya, serta mampu melayani masyarakat dengan menyandarkan pada aspek moralitas dan sumber daya manusia penegak hukum itu sendiri (Rahardjo, 2008:IX). Sehingga diperlukan perubahan terhadap materi peraturan perundangperundang yang mengatur pemilihan kepala daerah dengan calon tunggal.

Fenomena calon tunggal dalam pemilihan kepala daerah tahun 2018 muncul di beberapa daerah sebagaimana tabel 1 .

Tabel 1. Calon Tunggal dalam Pemilihan Kepala Daerah Tahun 2018

\begin{tabular}{|c|c|c|}
\hline No. & Kabupaten/Kota & Jumlah DPT \\
\hline 1. & $\begin{array}{ll}\text { Kabupaten } & \text { Padang } \\
\text { Lawas Utara } & \end{array}$ & 143.590 \\
\hline 2. & Kota Prabumulih & 125.866 \\
\hline
\end{tabular}




\begin{tabular}{clc}
\hline 3. & Kabupaten Tapin & 128.608 \\
\hline 4. & Kabupaten Mamasa & 111.655 \\
\hline 5. & Kabupaten Tangerang & 1.843 .188 \\
\hline 6. & Kota Tangerang & 1.027 .522 \\
\hline 7. & Kabupaten Jawawijaya & 268.416 \\
\hline 8. & Kabupaten Pasuruan & 1.151 .502 \\
\hline 9. & $\begin{array}{l}\text { Kabupaten Minahasa } \\
\text { Tenggara }\end{array}$ & 80.271 \\
\hline 10. & Kabupeten Enrekang & 149.115 \\
\hline 11. & Kabupaten Lebak & 926.342 \\
\hline 12. & $\begin{array}{l}\text { Kabupaten } \\
\text { Serdang }\end{array}$ & 1.165 .765 \\
\hline 13. & $\begin{array}{l}\text { Kabupaten Membrano } \\
\text { Tengah }\end{array}$ & 33.265 \\
\hline
\end{tabular}

Sumber: https://infopemilu.kpu.go.id/pilkada2018/ pemilih/dps/1 nasional.

Tabel tersebut menunjukkan bahwa calon tunggal dalam pemilihan kepala daerah tahun 2018 di 8 (delapan) daerah diikuti dengan jumlah pemilih yang kecil di bawah 500.000 pemilih dan 5 (lima) daerah dengan jumlah pemilih besar. Fakta ini menunjukkan bahwa pemilihan kepala daerah tahun 2018 diikuti oleh calon tunggal dengan jumlah pemilih yang relatif kecil. Peran uang dalam politik dan pemilu merupakan masalah besar untuk mereka yang ingin tetap terpilih dalam perkembangan demokrasi di seluruh dunia. Pemberian berupa apapun untuk memengaruhi keputusan pilihan seseorang atas pemimpin di dalam kontestasi pemilihan merupakan pelanggaran (Wibowo, 2013:186).

Politik uang dapat dikatakan merupakan endemi yang selalu timbul setiap kali pemilu namun selalu sulit pula mengungkap pelaku sekaligus memproses penindakannya (Najib, 2014:85-88). Banyak politisi bahkan menghalalkan segala cara untuk mengumpulkan dana kampanye, seperti korupsi (Zoelva, 2013:15). Politik uang diartikan sebagai seni untuk memperoleh kemenangan dalam memperebutkan kekuasaan. Sedangkan uang politik hanya sebagai akses untuk memperoleh kemenangan tersebut (Sumartini dalam Hastuti et al., 2012:4).

Politik dan demokrasi membutuhkan uang. Calon individu yang turut sebagai kontestan membutuhkan dana yang cukup untuk bisa mendapatkan suara pemilih. Uang bisa memengaruhi pemilih dalam menentukan pilihan, namun keberhasilan juga bisa terjadi kepada kontestan dengan uang sangat sedikit (Wardle, 2016:1). Pemilihan kepala daerah menghabiskan biaya yang sangat besar (Edwin, 2012:157). Biaya yang dikeluarkan calon kepala daerah bisa mencapai 100 miliar untuk provinsi dan 50 miliar untuk kabupaten/kota (Fitriah, 2012:1).

Fenomena calon tunggal terkini perlu disikapi berkenaan dengan hitungan biaya politik dan kesempatan terpilih bila harus berkompetisi dengan lebih dari satu calon. Atau lebih rendah biaya politik dengan kesempatan terpilih lebih besar jika pemilihan kepala daerah diikuti dengan calon tunggal. Fakta bahwa pemilihan kepala daerah tahun 2015 dan tahun 2017 dengan calon tunggal tidak pernah kalah tentunya merupakan daya tarik bagi individu atau kelompok yang akan berkompetisi dalam pemilihan kepala daerah. Dalam kalkulasi politik bagi calon kepala daerah yang akan berkompetisi lebih baik membeli dukungan kursi yang ada dalam DPRD, dibandingkan harus mengeluarkan biaya politik yang tinggi untuk bertarung bebas dalam kontestasi yang ada yang diikuti lebih dari satu calon.

32 kursi kongres terpilih tanpa saingan dalam pemilihan di Amerika Serikat tahun 2014; di Inggris 3\% dari anggota legislatif terpilih tanpa saingan; di Singapura sejumlah daerah pemilihan parlemen memiliki calon tunggal; 
dan di Kanada dan Skotlandia dalam pemilihan parlemen/legislatif. Di Irlandia terjadi pemilihan presiden dengan calon tunggal pada tahun 1938, 1952, 1974, 1976, 1983, dan 2004. Di Islandia pemilihan presiden dengan calon tunggal terlaksana pada 1992 dan 2000. Di Singapura pemilu presiden dengan calon tunggal terjadi tahun 1999 dan 2005. Di negara lain pemilihan tetap dilangsungkan dan pemilih dihadapkan pada pilihan.

Mencontoh model pemilihan tentu tidak salah. Namun pemahaman dan pengetahuan masyarakat Indonesia harus diperhatikan. Kesadaran demokrasi dan tingkat pengetahuan pemilih tentu tidak sebanding dengan negara yang sudah maju. Melepaskan model calon tunggal dalam pemilihan kepala daerah tanpa adanya konstruksi hukum yang dapat meningkatkan kesadaran demokrasi dan politik masyarakat hanya akan merusak nilai demokrasi tersebut (www.nasional.okezone.com).

Hukum progresif dimulai dari asumsi dasar filosofis bahwa hukum adalah untuk manusia bukan sebaliknya. Dengan demikian keberadaan hukum adalah untuk melayani dan melindungi manusia bukan sebaliknya. Hukum dianggap sebagai institusi yang bertujuan mengantarkan manusia kepada kehidupan yang adil dan sejahtera, dan membuat manusia bahagia. Hukum progresif menganut ideologi hukum yang pro-keadilan dan hukum yang pro-rakyat (Rahardjo, 2009:6).

Progresivisme hukum pada prinsipnya keberadaan hukum sesungguhnya untuk melindungi manusia sebagai pengguna hukum. Hukum dibuat untuk manusia, sehingga hukum yang dibuatharuslahhukumyangberkemanusiaan. Dalam gerakan hukum progresif, manusia berada di atas hukum, hukum hanya dijadikan sarana untuk menjamin dan menjaga berbagai kebutuhan manusia. Sehingga bilamana hukum pemilihan kepala daerah dengan calon tunggal dalam bekerjanya tidak memberikan keadilan dan kesejahteraan serta menuju kepada kebahagiaan, maka hukum tersebut harus segera dirubah.

Pemilihan kepala daerah sebagai wujud pelaksanaan kedaulatan rakyat diselenggarakan sebagaimana Pasal 18 ayat (4) UUD NRI 1945 juga mengamanatkan bahwa kepala daerah harus dipilih secara demokratis. Bahwa Putusan Mahkamah Konstitusi merupakan putusan yang bersifat final dan mengikat yang dijadikan dasar konstitusional pelaksanaan pemilihan kepala daerah dengan calon tunggal harus dihormati.

Fakta terkini pemilihan kepala daerah dengan calon tunggal perlu dikawal sehingga pemilihan tetap berlangsung secara demokratis. Kerangka hukum harus menjamin pembatasan maksimal dukungan kursi calon kepala daerah yang diusung partai politik atau gabungan partai politik, sehingga dapat menghilangkan monopoli individu atau kelompok pemodal terhadap persyaratan dukungan calon kepala daerah.

Kerangka hukum juga harus mengurangi persentasi dukungan akumulasi perolehan suara sah dalam pemilu terakhir dalam hal dukungan bagi partai politik atau gabungan partai politik dalam mengusung calon kepala daerah. Hal ini dilakukan untuk membuka ruang munculnya calon lain yang tidak mendapat kursi, namun menggunakan dukungan suara dari jumlah kursi DPRD. Kerangka hukum mempermudah dan mengurangi jumlah dukungan dan persebaran bagi pasangan calon perseorangan merupakan usaha untuk memunculkan calon yang siap berkompetisi dalam pemilihan kepala daerah. Banyaknya calon kepala daerah yang 
berkompetisi memberikan pilihan yang luas dan beragam terhadap pemilih.

\section{KESIMPULAN}

Calon tunggal dalam pemilihan kepala daerah memerlukan konstruksi hukum yang tepat (tidak dibiarkan terlepas) untuk menjamin demokrasi berjalan secara demokratis pasca Putusan Mahkamah Konstitusi Nomor 100/PUUXIII/2015. Perubahan undang-undang berupa pembatasan maksimal dukungan kursi calon kepala daerah yang diusung partai atau gabungan partai politik, mengurangi persentasi dukungan perolehan suara sah bagi partai atau gabungan partai politik, mempermudah dan mengurangi jumlah dukungan dan persebaran pasangan calon perseorangan, dan membuat model sosialisasi pemilihan kepala daerah dengan calon tunggal dalam rangka menjaga berlangsungnya pemilihan kepala daerah yang demokratis.

\section{SARAN}

1. Dimasukkan sanksi bagi partai politik yang masih memungkinkan mengusung calon kepala daerah namun tidak mengusulkan calon kepala daerah.

2. Penyelenggara pemilu dan seluruh pemangku kepentingan yang fokus dalam pembangunan demokrasi dan pemilu perlu menyiapkan model sosialisasi pemilihan kepala daerah dengan calon tunggal. Mengkampanyekan calon yang berkompetisi tunggal dalam pemilihan kepala daerah mudah dilakukan. Namun kotak kosong (Tidak Setuju) tidak bisa mengkampanyekan dirinya kepada pemilih merupakan kenyataan tak terbantahkan.
3. Partai politik berperan dalam meningkatkan kualitas demokrasi. Maju dan mundurnya demokrasi suatu negara berada ditangan partai politik. Partai politik mempunyai peluang untuk mencalonkan pasangan lain sebab pencalonan kepala daerah merupakan bagian dari rekrutmen politik. Partai politik dapat melakukan pendidikan politik kepada anggotanya. Partai politik dapat membangun sekolah politik untuk menciptakan kader partai yang berintegritas dan profesional. Hal ini dilakukan agar kader partai tersebut mempunyai nilai yang baik di masyarakat sehingga layak berkompetisi. Partai tidak ragu untuk mencalonkan atau sibuk mencari figur di luar partai. Partai politik percaya diri untuk mencalonkan calon kepala daerah yang diambil dari partainya sendiri. Hal ini tentunya menguntungkan masyarakat pemilih karena partai politik berhasil menampilkan lebih banyak calon yang notabene berasal dari partai politik (rumah) sendiri. Ukuran keberhasilan partai politik modern melakukan pendidikan politik bila banyak anggota partai mempunyai daya jual sehingga percaya diri untuk mencalonkan anggotanya dalam kontestasi pemilihan kepala daerah.

\section{DAFTAR ACUAN}

\section{Buku}

Asshiddiqie, J. (2011). Pengantar ilmu hukum tata negara. Jakarta: PT Raja Grafindo.

Burns, J.M., Peltason, J.W., \& Cronin, T.E. (1989). Government by the people. New Jersey: 
Englewood Cliffs.

Hague, R. \& Harrop, M. (2001). Comparative government \& politics an introduction. New York: Palgrave.

Harjanto, N. (2011). Politik kekerabatan \& institusionalisasi partai politik di Indonesia. Jakarta: Analisis CSIS.

Hastuti et al. (2012). Politik uang dalam pemilihan kepala desa Cangkringan \& desa Dawuhan kecamatan Talang kabupaten Tegal. Semarang: Universitas Diponegoro.

Hix, S. \& Whiting, M. (2012). Introduction to political science. London: University of London.

Huda, N.H. (2005). Hukum Tata Negara Indonesia. Jakarta: PT. Raja Grafindo Perkasa.

Huntington, S.P. (1989). The modest meaning of democracy. New York: Holmes and Meier.

Karim, M.R. (1991). Pemilu demokrasi komperatif. Yogyakarta: Tiara Wacana.

Maciver, R.M. (1955). The modern state. London: Oxford University Press.

Maschab, M. (2013). Politik pemerintahan desa di Indonesia. Yogyakarta: Polgov Universitas Gajahmada.

Moleong, L.J. (2012). Metodologoi penelitian qualitatif. Bandung: PT Remaja Rosda Karya.

Najib, M. et al. (2014). Pengawasan pemilu problem \& tantangan. Yogyakarta: Bawaslu Provinsi DIY.

Noer, D. (1983). Pengantar ke pemikiran politik. Jakarta: PT Rajawali.

Nurhasim, M. (Ed). (2014). Partisipasi pemilih pada pemilu 2014: Studi penjajakan. Jakarta: Pusat Penelitian Politik LIPI bekerjasama dengan
Komisi Pemilihan Umum.

Nurtjahjo, H. (2006). Filsafat demokrasi. Jakarta: Bumi Aksara.

Office for Democratic Institutions and Human Rights (2002). Statement to the United Nations Commission on Human Rights at its 58th Session. Geneva: Ambassador Grard Stoudmann.

Pamungkas, S. (2009). Perihal pemilu. Yogyakarta: Laboratorium Jurusan Pemerintahan Fisipol UGM.

Pangi, S. (2012). Titik balik demokrasi. Jakarta: Pustaka Inteligensia.

Prodjodikoro, W. (1981). Asas-asas ilmu negara \& politik. Cetakan ke-2. Jakarta: PT Eresco.

Rahardjo, S. (2008). Membedah hukum progresif. Jakarta: Kompas. . (2009). Hukum progresif sebuah sintesa hukum Indonesia. Yogyakarta: Genta Publishing.

Rivai, A. (2010). Penemuan hukum oleh hakim dalam perspektif hukum progresif. Jakarta: Sinar Grafika.

Schumpeter, J. (1974). Capitalism, socialism, \& democracy. New York: Harper.

Supriyanto, D. \& Wulandari, L. (2012). Bantuan keuangan partai politik: Metode penetapan besaran, transparansi \& akuntabilitas pengelolaan. Jakarta: Perludem.

Thaib, D. (1999). Kedaulatan rakyat negara hukum \& konstitusi. Yogyakarta: Liberty.

Wardle, P. (2016). Cost of politics. London: Westminster Foundation For Democracy.

Wibowo, P.A. (2013). Mahalnya demokrasi 
memudarnya ideologi. Jakarta: Kompas Media Nusantara.

World Economic Forum [WEF]. (2017). The Global Human Capital Report 2017. Geneva Switzerland.

\section{$\underline{\text { Jurnal }}$}

Edwin, D. (2012). Pemilukada \& perilaku korupsi kepala daerah. Jurnal Komunitas, 6(2), 157165.

Fitriah. (2012, April). Fenomena politik uang dalam pilkada. Jurnal Politika, 1(1), 1-11.

Gaffar, J.M. (2013). Peran putusan Mahkamah Konstitusi dalam perlindungan hak asasi manusia terkait penyelenggaraan pemilu. Jurnal Konstitusi, 10(1), 1-31.

Rahardjo, S. (2005, April). Hukum progresif: Hukum yang membebaskan. Jurnal Hukum Progresif, 1(1), 1-24.

Zoelva, H. (2013). Memberantas electoral corruption. Jurnal Pemilu dan demokrasi, 5(5), 1-28.

\section{$\underline{\text { Sumber lainnva }}$}

https://infopemilu.kpu.go.id/pilkada2018/pemilih/ dps/1/nasional. Diakses tanggal 30 April 2018. Inter-Parliamentary Union (IPU). (1997). Universal Declaration on Democracy. Cairo: Cairo International Conference.

www.nasional.okezone.com. Diakses 1 April 2018. 